\title{
Erratum to: Glutathione and Malondialdehyde Levels in Late Pulmonary Complications of Sulfur Mustard Intoxication
}

\author{
Majid Shohrati • Mostafa Ghanei • Navvab Shamspour • \\ Fatemeh Babaei · Majid Norozi Abadi • Mahvash Jafari • \\ Ali Amini Harandi
}

Published online: 16 December 2009

(C) Springer Science+Business Media, LLC 2009

\section{Erratum to: LUNG}

DOI 10.1007/s00408-009-9178-y

Unfortunately, the name of last author has been cited incorrectly. His full name is "Ali Amini Harandi" (given name: Ali Amini; family name: Harandi) and so should be cited as "Harandi AA" as in previous citations.

The online version of the original article can be found under doi:10.1007/s00408-009-9178-y.

M. Shohrati $(\bowtie) \cdot$ M. Ghanei · M. N. Abadi · M. Jafari ·

A. A. Harandi

Research Center of Chemical Injuries, Baqiyatallah Medical,

Sciences University, Mollasadra Street, P.O. Box 19945-546,

Tehran, Iran

e-mail: shohratimajid@yahoo.com; shohrati@bmsu.ac.ir

\section{N. Shamspour}

Institute of Applied Science and Technology,

Red Crescent Society of Iran, Tehran, Iran

F. Babaei

Payame Noor University of Tehran, Tehran, Iran

e-mail: f.babaei2007@gmail.com 